\title{
An Agent of Change Against all Odds? The Case of Ledger in Vierzon, France
}

Arnault Morisson ${ }^{1}$ and Heike Mayer ${ }^{1}$

${ }^{1}$ Institute of Geography \& Centre for Regional Economic Development (CRED)

University of Bern, Switzerland.

e-mail: arnault.morisson@giub.unibe.ch

This is an accepted manuscript (preprint) of an article published in Local Economy available online: https://journals.sagepub.com/doi/10.1177/02690942211052014

Please cite (APA Style): Morisson, A. \& Mayer, H. (2021). An Agent of Change Against all Odds? The Case of Ledger in Vierzon, France. Local Economy, forthcoming.

doi.org/10.1177/02690942211052014 


\title{
An Agent of Change Against all Odds? The Case of Ledger in Vierzon, France
}

\begin{abstract}
The literature in economic geography is increasingly interested in the role of human agency in local and regional development. The understanding of the role of agents of change on path development is especially critical for small- and medium-sized towns (SMSTs), which tend to be less diversified and to have fewer localised capabilities. The town of Vierzon in the CentreVal-de-Loire region in France is a medium-sized old-industrial town in a structural crisis. It is suffering from deindustrialisation, population decline, unemployment, and poverty. This article takes a micro-perspective with a case-study approach to explore the creation and growth of Ledger-a frontier blockchain start-up that designs, produces, and commercialises hardware wallets for cryptocurrencies-against all odds in Vierzon, France. It underlines the role of a Window of Locational Opportunity (Scott \& Storper, 1987), agency, chance, the broader institutional context in the location of Ledger in an unlikely place and subsequent unrelated diversification and path creation. It contributes to the debate on the interplay between agency and structure by linking agents of change in SMSTs to the broader institutional context and to the understanding of the emergence of place-based leadership.
\end{abstract}

\section{Keywords:}

France; Medium-sized towns; path development; agents of change; Window of Locational Opportunity.

\section{Introduction}

The literature in economic geography is increasingly interested in understanding the role of human agency in local and regional development (see Crespo, 2021; Döringer, 2020; Grillitsch \& Sotarauta, 2020; Miörner, 2020; Simmie, 2020). Gregory et al. (2009, p. 347) defines human agency as "the ability of people to act, usually regarded as emerging from consciously held intentions, and as resulting in observable effects in the human world". Economic geography considers agents of change within the neo-Schumpeterian tradition where multiple types of "entrepreneurs" not only affect new industrial path development but also instigate institutional changes. New industrial path development is the outcome of existing localised capabilities, which are path-dependent (Hassink et al., 2019).

Agents of change play a fundamental role during Windows of Locational Opportunity (WLO) (Boschma, 1997; Scott \& Storper, 1987) and are often the actors who can break existing path dependencies to drive regional change (Boschma, 2007; Grillitsch \& Sotarauta, 2020). The WLO-concept states that the emergence of new technologies offers greater opportunities for chance in new industrial path development because it represents a fundamental break with the past (Boschma \& van der Knaap, 1997; Scott \& Storper, 1987). Blockchain-the technology behind cryptocurrencies which emerged with the creation of Bitcoin in 2008-can integrate into multiple applications in a decentralised manner (Zheng et al., 2018). Blockchain technology thus offered a WLO as the disruptive computing technology represente da clear technological break from the past.

The understanding of the role of agents of change on new industrial path development is especially critical for unlikely places or small- and medium-sized towns (SMSTs) in peripheral regions (Tödtling \& Trippl, 2005). These, have largely been neglected due to an urban bias in economic geography (Servillo et al., 2017). They are less diversified making path creation more difficult (Neffke et al., 2011; Pylak \& Kogler, 2021), prone to lock-ins due to dominant industrial structures (Bole et al., 2020), or have less policy autonomy to 'manage' their socioeconomic development (Hamdouch et al., 2017). There is, however, increasing evidence that SMSTs can use compensation and exploitation strategies to innovate and become successful 
entrepreneurial ecosystems (Eder \& Trippl, 2019; Roundy, 2017). Moreover, in the European Union, SMSTs are becoming more attractive places to work and live with potential for growth (Dijkstra et al., 2013; Rodríguez-Pose \& Griffiths, 2021) calling for more contextualised placebased policies (Barca et al., 2012).

The article takes a micro-perspective to explore the creation and growth of Ledger, a frontier unicorn start-up that designs, produces, and commercialises hardware wallets for cryptocurrencies, against all odds in Vierzon, France. The case of Ledger in Vierzon contributes to the academic debate in three ways. First, it captures how agents of change seized a brief WLO in a SMST in a peripheral region to engage in path creation and unrelated diversification. Second, it sheds light on howagency and structure mediated the WLO, chance, and serendipity. Third, it provides new evidence on the emergence of institutional entrepreneurship and place-based leadership to promote path creation in the SMSTs context (Beer, 2014).

The article asks two research questions. First, what factors enable start-ups to seize and pursue a WLO in SMSTs in peripheral regions? Second, how does place-based leadership emerge in SMSTs and what is its role on new industrial path development? Ledger, which is the outcome of Schumpeterian innovative entrepreneurs, is located in an unlikely place making it an outlier case that contrasts with the macro-perspective taken in evolutionary economy geography (EEG) (Asheim et al., 2011) and the system-perspective taken in regional innovation system (RIS) to understand regional structural changes (Hassink et al., 2019). While Ledger specialises in frontier blockchain technologies, Vierzon is an old industrial medium-sized town in a peripheral French department that suffers from declining population, deindustrialisation, poverty, and structural unemployment (INSEE, 2021).

The article finds that the role of chance and serendipity was central for the entrepreneurs to seize the WLO in Vierzon. The French institutional context that promotes entrepreneurship and economic development through regional public actors - like the public investment bank BPI France-and regional and local development agencies mediated the factor of chance. As a result, the case illustrates the interplay between agency and structure us ing an institutional perspective to analyse the French institutional context. Moreover, it informs on the early processes leading to the emergence of place-based leadership in a SMST. The rest of the article consists of four parts. First, it presents the theoretical approach on agents of change and institutional context. Second, a methodological section outlines how the original empirical data were collected and analysed. Third, it presents the empirical case study of Ledger in Vierzon. Fourth, the main results are reported and discussed, before concluding.

\section{Theoretical framework}

The literature on regional path creation and particular on the question how new industries and entrepreneurial activities emerge in unlikely places has started to recognise the role of human agency (Isaksen et al., 2019; Grillitsch \& Sotarauta, 2020). In this paper, we would like to draw attention to theoretical concepts that were developed even earlier than this most recent work on agency. We intend to show that for institutional entrepreneurship and place-based leadership to emerge in an unlikely place such as a small- or medium-sized town (SMST) in a peripheral region, a Window of Locational Opportunity (WLO) and respectively, an agentspecific opportunity space has to open up.

Developed in the 1980s and 1990s, the Windows of Locational Opportunity (WLO) concept provides an analytical framework to explain path creation in unlikely places during the emergence of an innovative technology (see Boschma, 1997; Scott \& Storper, 1987; Storper \& Walker, 1989; Perez \& Soete, 1988). Contingent upon generic resources relevant to the development of that innovative technology, the role of chance and agency are particularly important for path creation, and unrelated diversification, before increasing returns and 
supporting institutions curb the WLO (Boschma \& van der Knaap, 1997). The WLO-concept hints at greater unpredictability in path creation and unrelated diversification. Along these lines, Boschma (1997) argues that "the importance of spatial indeterminacy leaves room for human agency or creativity to be involved in the spatial formation of newly emerging industries" ( $p$. 13).

The WLO-concept has been applied to explain catch-up during the formation of sectors or the introduction of radical innovations. This is true, for instance, with digital TV in Korea or cleantech in China (Gosens et al., 2021; Lee et al., 2005). These examples hint at the role of the institutional context in capturing WLO in unlikely places. As a result, unlikely places in national institutional frameworks where generic resources are more equally distributed might have a higher chance at capturing a WLO. France is characterised by the strong role of the State, welfare state, and dirigiste capitalism that has pursued multiple territorial equality policies since the 1950s spearheaded with the creation of DATAR in 1963 (Béhar, 2019). French State policies are increasingly entangled with those pushed by the European Union, leading to multiple rounds of 'modernisation' that has transformed the country into a form of a stateinfluence market economy (Schmidt, 2009). In 2013, the French State launched programs promoting entrepreneurship and start-up ecosystems across French regions. These included the French Tech Initiative and the consolidation of the public investment bank, BPI France. State initiatives towards promoting start-ups, spearheaded by this French Tech initiative exemplify this shift towards a state-influence market economy.

Newer writings in economic geography on the notion of the opportunity space point to similar aspects and note that there can be time-specific, region-specific, and agent-specific opportunity spaces (Grillitsch \& Sotarauta, 2020). The opportunity space, which is the agents' perception that change is possible at a certain time and space, offers an understanding of the interplay between agency and structure (Grillitsch \& Sotarauta, 2020; Sotarauta et al., 2021). Agents of change can construct or exploit opportunity spaces, which mediate the interplay between structure and agency, to foster changes. Grillitsch and Sotarauta (2020, p. 713) point out that "agents reflect in a strategic manner considering how structures may evolve in the future and considering how their actions might affect this evolution". Yet, it is unclear how and at what point in time the opportunity space is constructed in the first place. The WLO-concept fills this gap showing that Schumpeterian innovative entrepreneurs can also construct the opportunity space in regions that are not yet structured to optimally support emerging technologies. As Boschma (1997, p.14) points out, "the presence of high returns in the early stages of growth, which result from patent protection, technological inappropriability and (temporary) price inelastic demand allows new industries to locate and survive in arbitrary places".

The WLO-concept, however, does not address the evolutionary aspects of new path creation in regions that follow once the opportunity emerges. Grillitsch and Asheim (2018) distinguish three categories of new industrial path development, namely upgrading, divers ification, and the emergence of new regional industrial paths. Upgrading refers to major changes in existing industries. Diversification can be related or unrelated to the existing scientific and technological knowledge base. Emergence refers to unrelated industries either through path creation or path importation. Although unrelated diversification has a greater impact on economic growth (see Pinheiro et al., 2018), related diversification is the rule, while unrelated diversification is the exception (Boschma, 2017). In SMSTs, diversification and emergence are more difficult to achieve due to lower urbanisation economies (Jacobs, 1969).

While the WLO-concept is quite clear about the emergence of newindustries in unlikely places, it does not provide a good theoretical framework for conceptualising the role of agents of change. This is especially true in the context of organisationally thin small and medium-sized towns (SMSTs) in peripheral regions (Tödtling \& Trippl, 2005). Grillitsch and Sotarauta (2020) introduce the concept of the trinity of change agency, namely Schumpeterian innovative 
entrepreneurs, institutional entrepreneurs, and place-based leadership, to put back the spotlight on human agencies in the creation of new industrial path development. As a result, depending on their intentions towards changes, agents of change can be institutional entrepreneurs (Weik, 2011) or Schumpeterian innovative entrepreneurs (Grillitsch \& Sotarauta, 2020), and can rally multiple actors around a shared vision of the future to form place-based leadership (Beer \& Clower, 2014; Sotarauta, 2016). Agents of change are embedded into the broader institutional context that determines the agents' behaviours and expectations linked to the agency-structure debate (Battilana et al., 2009). As a result, changes are mediated by pre-existing institutions embedded in a structure that is time- and spacespecific (Moulaert, Jessop, \& Mehmood, 2016).

A Schumpeterian innovative entrepreneur is a person or group of persons who has the capacity, motivation, and willingness to transform an idea into an innovation and thus employs "the gale of creative destruction" to replace inferior innovations and thus incumbents (Schumpeter, 1942). Schumpeterian innovative entrepreneurship is a risk-taking and nonroutine behaviour to realise new possibilities, combinations, and practical actualisation (Feldman et al., 2005; Neffke et al., 2011; Strambach \& Klement, 2012). These entrepreneurs are the agents who identify emerging technologies and novel market opportunities allowing them to seize WLO and expand opportunity spaces. As a result, they are able to break existing path development and create new paths (Grillitsch \& Sotarauta, 2020).

In the literature, the study of Schumpeterian innovative entrepreneurs suffers from a high urban bias to the extent that these agents of change are almost exclusively seen as a metropolitan phenomenon (see Adler et al., 2019; Low \& Isserman, 2015). This is even more surprising since the study of new industrial spaces in the 1980s and 1990s put a spotlight on unlikely places and in more recent years, scholars have turned their attention to the development of secondary and/or peripheral regions (Eder, 2019; Eder \& Trippl, 2019; Grabher, 2018; Mayer, 2011). Despite their limitations, SMSTs can offer some advantages. For instance, they can add denser social networks and place-specific assets (such as lower labour and housing costs) to the development of vibrantentrepreneurial communities (Roundy, 2017). Moreover, due to their dense social networks and weaker endowments, SMSTs can offer more institutional leeway in creating of a supportive environment during the birthing phase of an entrepreneurial ecosystem (Eder \& Trippl, 2019; Mack \& Mayer, 2015).

Institutional entrepreneurs thus facilitate the creation of a supportive environment to construct the opportunity space. They are actors who mobilise resources, power, and competences to transform existing institutions by introducing new institutions or institutional arrangements (Battilana et al., 2009; Sotarauta \& Pulkkinen, 2011). These entrepreneurs usually have a strong interest in shaping institutional arrangements and institutional changes. They tend to act when the agents identify windows of opportunity (Battilana et al., 2009). Institutional entrepreneurs are the agents who promote institutional changes in formal or informal institutions (North, 1990). Formal institutions are the 'rules that humans devise', such as laws, constitutions, government regulations, formal instructions, and property rights, which affect transaction costs (North,1990, p. 4). Informal institutions are 'the conventions and codes of behaviour' such as common law, customs, traditions, taboos, codes of conduct, work nor ms, norms of cooperation, conventions, and practices (North,1990, p. 4). Institutional changes are especially important in a period of path creation and transformation to better align institutions and the emerging techno-economic structures (Morisson \& Panetti, 2020; Trippl et al., 2020). Institutional entrepreneurs create opportunities for the emergence of new paths, which can offer a theoretical understanding of how paths emerge in less diversified SMSTs (Sotarauta \& Mustikkamäki, 2015).

The third type of agency involves place-based leadership, a form of collective leadership involving multiple actors to coordinate regional development efforts (Sotarauta et al., 2017). The concept of place-based leadership does not focus on the individual charismatic agent but 
rather on the collective strategic agency to coordinate and rally diverse stakeholders around a common vision of the future to drive changes (Beer \& Clower, 2014). Place-based leadership works across institutional, organisational, geographical and/or sectoral boundaries to amplify the local power base and consequently strengthen its capacity to influence its development trajectory (Sotarauta, 2020). Centralised governments are less likely to encourage the rise of effective local leadership (Beer \& Clower, 2014; Sotarauta \& Beer, 2017). In rural Australia for instance, leadership was constrained by the capacity of broker agents across multi-level governance structures (Beer, 2014). Place-based leadership bridges the issue of human agency versus structure. The broader institutional context can thus enable or constrain placebased leadership.

\section{Methodology}

This article's research methodology employs a single in-depth case study to explore the location of Ledger in Vierzon, France, and its impact on the local context. A case study approach was selected 'out of the desire to understand complex social phenomena' in which the researcher has no control (Yin, 2013, p. 4). The case of Ledger in Vierzon was purposefully sampled because of its outlier characteristics. The selected case is significant since it provides 'a rich and deep understanding of the subject and breakthrough insights.' It is high impact since it provides 'a significant contribution' to the literature on agents of change and unrelated diversification in an outlier context (Patton, 2015, p. 267). Purposeful sampling provides an 'information-rich case' and can inform local policymakers on place-based policies to seize WLO to break technological path dependencies (Patton, 2015, p. 230).

Research on agents of change implies asking the question who did what, when, where, why, how, with whom and to what consequence making qualitative research a particularly suitable methodology (Grillitsch et al., 2021). Qualitative research implies an extensive collection of data from multiple sources of information (Creswell, 2013). The research strategy aimed to generate a timeline of events and understand the actions directed towards achieving change (Grillitsch et al., 2021). SMSTs' context is conducive to the research on agents of change thanks to the limited number of easily identifiable actors within clearly defined spatial and temporal boundaries. The research conducted for this article is based on three main sources of data: semi-structured interviews, documents, and direct observation.

Researchers conducted 12 semi-structured interviews by phone due to COVID-19 restrictions from December 2020 to March 2021-lasting from 30 to 75 minutes - to gather extensive data on aspects of the research question. The expert semi-structured interviews were conducted with Ledger's founding team from Vierzon and employees, local and regional institutional actors, a higher educational institution, and civil society (see Table 1). The interviewees were selected as key informants within a snowball technique. The documents collected for this research aimed to generate a timeline of events and actions related to the development of Ledger and came from four sources: articles in national and regional newspapers such as $L e$ Monde, La Tribune, Le Berry Républicain, local blogs like Vierzonitude, and institutional websites such as BPI, Dev'Up, or City of Vierzon, newsletters from the Intercommunality; official documents, such as INSEE statistical data and municipal documents; and Ledger's own websites. In February 2021, living in the department, one of the researchers visited the Sologne Technology Park, downtown Vierzon, the local industrial areas, and Société Française de Vierzon to gain a better sense of the local context. This direct observation aimed to cross-check if any actors or urban projects were overlooked in the desktop research and analysis. 


\begin{tabular}{lc}
\hline \multicolumn{1}{c}{ Actors } & $\begin{array}{c}\text { Number of } \\
\text { interviews }\end{array}$ \\
\hline Ledger & 5 \\
Municipality of Vierzon & 1 \\
Intercommunality of Vierzon & 3 \\
Civil society (blog) & 1 \\
Higher Education Institution & 1 \\
Regional Development Agency - Dev' up & 1 \\
Total & 12 \\
\hline
\end{tabular}

Table 1. Interviews conducted. Source: own design.

The data analysis consisted of triangulating the gathered information to "produce empirically based findings' (Yin, 2013, p. 132), with the objective of exploring the creation of Ledger in Vierzon and its impact on the local context using the agency's perspective, trinity of change agency concept, and new industrial path development as conceptual frameworks. The case of Ledger was analysed to understand how the agents successfully seized the WLO and the agents' choice and motivation to locate and remain in Vierzon. Moreover, the case of Ledger in Vierzon was analysed in relation to the local, regional, and national institutional contexts to understand interactions among different stakeholders in Ledger's development and impact on local economic development. Validation is achieved through triangulation of multiple sources of evidence to ensure that 'the right information and interpretations have been obtained' and convergent line of inquiry (Stake, 2013, p. 36). Validity is also achieved through participants' checking, where two key interviewees were solicited to provide "critical observations or alternative interpretations" (Stake, 1995, p. 115). The context-rich and in-depth descriptions offer policymakers insights on how to contextualise the findings and design place-based policies.

\section{Case-study}

\section{Vierzon - Context}

Vierzon is a medium-sized town of 25,903 inhabitants in 2017 in the department of Cher in the Centre-Val de Loire Region in France (See Map 1). The Intercommunality of Vierzon-SologneBerry, which includes Vierzon and fifteen neighbouring communes, oversees local economic development. Vierzon is marked politically on the far left, and since 2008, Nicolas Sansu, a member of the French Communist Party, has been Mayor. Vierzon is the second-ranked most populous town after the department prefecture, Bourges, which had 64,551 inhabitants in 2017. Cher is a rural department with a declining industrial sector, whose share of the employed population fell from 18.8 percent in 2007 to 15.6 in 2017 (INSEE, 2021). Public administration is concentrated in Bourges, which also has some industries related to defence - with missile manufacturer MBDA and munitions with Nexter-and aeronautics, mechanics, and electronics and sensors (DDT, 2020). The department is also home of numerous agri-food industries. 


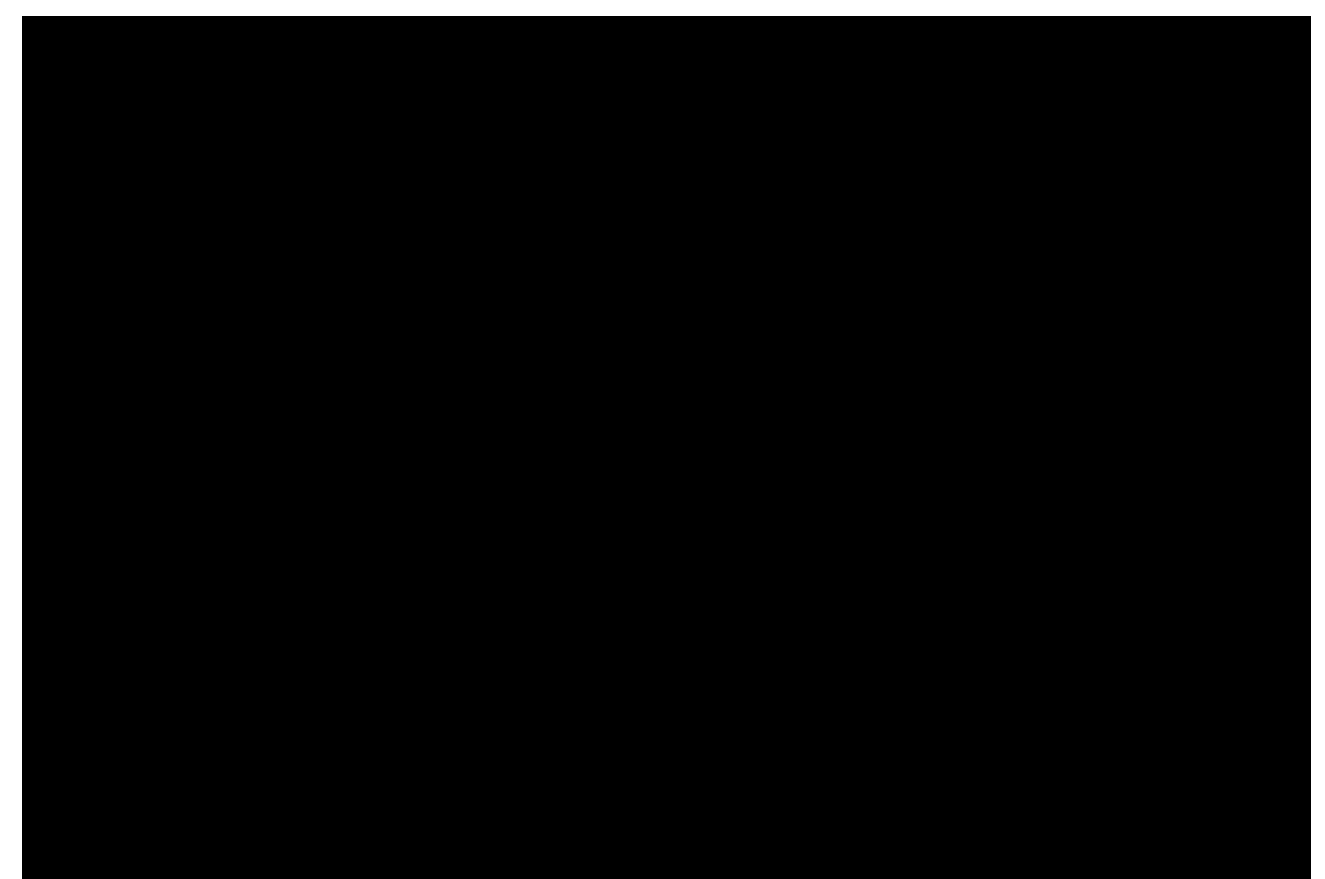

Map 1. Map of France, Centre-Val de Loire, Cher, and location of Vierzon. Source: own design.

Vierzon used to be an important industrial town known for its porcelain and tractors (DDT, 2020). The porcelain sector emerged from the strategic location of Vierzon on the LimogesParis axis and transportation infrastructures. The Schumpeterian innovative entrepreneur, Marc Larchevêque, who transformed the family-owned porcelain manufacturer by introducing new industrial processes and founded the ceramic section at the Ecole Nationale Professionnelle in 1921 was a central actor in Vierzon's porcelain development (Le Berry, 2018). Vierzon had 14 porcelain manufacturers in the early $20^{\text {th }}$ century, which declined after World War II, with the last manufacturer closing in 2014 (DDT, 2020). The second important industrial sector was the tractor manufacturing led by the Société française de Vierzon that grew rapidly from the 1930s to the 1950s before entering crisis due to increased American competition with the Marshall plan. The Société Française de Vierzon was bought in 1958 by the American company Case to build heavy equipment and closed in 1995.

With the decline of its industrial sector after World War II accelerating in the 1990s, Vierzon has endured a deep structural crisis. Indeed, key structural indicators show population decline from a peak of 35,699 inhabitants in 1975, structural unemployment, deindustrialisation, a poverty rate significantly higher than in the rest of the department, region, and country (see Table 2). The town is experiencing a decline of its main street with one of the highest retail vacancy rates in France up to 23.4 percent in 2016 (Chocron, 2019). Vierzon benefits from national urban regeneration programmes such as "Action Coeur de Ville" that aims to revitalise medium-sized towns urban centres. In 2019 , a public square, a $€ 5.4$ million urban regeneration project in downtown Vierzon, was inaugurated. The building B3 of the Société Française de Vierzon, an 18,000 square-meter industrial structure in the town centre, is being rehabilitated with the objective to open a digital campus in 2023 (CDC INFOS, 2021). 


\begin{tabular}{|c|c|c|c|c|}
\hline Indicators & Vierzon & $\begin{array}{c}\text { Cher } \\
\text { (Department) }\end{array}$ & $\begin{array}{l}\text { Centre-Val-de- } \\
\text { Loire (Region) }\end{array}$ & $\begin{array}{c}\text { France } \\
\text { (Metropolitan) }\end{array}$ \\
\hline Population in 2017 (2007) & $\begin{array}{c}25903 \\
(27723)\end{array}$ & $\begin{array}{c}304256 \\
(314600)\end{array}$ & $\begin{array}{c}2576252 \\
(2526902)\end{array}$ & $\begin{array}{c}64639133 \\
(61795007)\end{array}$ \\
\hline Population change (2007-2017) in \% & $(-) 6.6$ & $(-) 3.3$ & 2 & 4.6 \\
\hline Household median revenue in 2018 , in euros & 18190 & 20880 & 21560 & 21730 \\
\hline Poverty rate in 2018 , in $\%$ & 24 & 14.3 & 13.1 & 14.6 \\
\hline Participation rate ( 15 to 64 years old) in 2017 & 70.6 & 74 & 74.9 & 74.1 \\
\hline Unemployment rate ( 15 to 64 years old) in 2017 & 23.6 & 13.9 & 12.9 & 13.4 \\
\hline \multicolumn{5}{|l|}{ Employment per sector in \% in 2017 (2007) } \\
\hline Agricultural sector & $1.1(0.8)$ & $5.5(5.7)$ & $3.5(4)$ & $2.6(3.1)$ \\
\hline Industrial sector & $14.6(20.8)$ & $15.6(18.8)$ & $15.6(18.6)$ & $12.2(14.8)$ \\
\hline Construction & $4.7(4.6)$ & $6.2(6.8)$ & $6.8(7.3)$ & $6.4(6.8)$ \\
\hline Tertiary sector & $38(37.5)$ & $37.7(35.5)$ & $41,7(39.7)$ & $46.8(45.1)$ \\
\hline Public administration & $41.6(36.3)$ & $35(33.2)$ & $32.4(30.4)$ & $32(30.3)$ \\
\hline
\end{tabular}

Table 2. Key socio-economic indicators in Vierzon compared to the department, region, and metropolitan France. Source: INSEE (2021) —POP T0, EMP T1, EMP T4, EMP T8, REV G1, and REV T1.

Being in the centre of France, Vierzon is an important transportation hub with three highways and railways. The main private companies are automobile suppliers such as Paulstra or the Japanese company Koyo Bearings, light manufacturing companies such as American Honeywell, and logistics companies. Vierzon was home to ICERMA, a research and technology centre on ceramics and advanced materials, and PROTO-Centre to support industrial prototyping at the Lycée Henri-Brisson. In 2010, the Sologne Technology Park, receiving European Regional Development Funds (ERDF) and public funding, was created on 87 hectares to attract industrial and logistic companies, as noted "the creation of the Sologne technology park in 2008 came from the assessment that there was no space and serviced land for companies and that we could miss some opportunities" (personal communication, 9 March 2021). The Technology Park offers multiple services such as office spaces for start-ups and private companies but also incubation and shared services such as fast-internet and meeting rooms. In 2019, a branch of the CETIM, a regional initiative to promote digitalisation and industry 4.0, located in the Sologne technology park. As of 2021, a project to build a large logistics platform of 80,000 square-meter on 17 hectares in the Sologne technology park is ongoing (CDC INFOS, 2021).

\section{From RadioceRos to Chronocoin}

In 2012, Joël Pobeda and David Balland founded RadioceRos, a start-up to livestream music, in Vierzon. Before launching RadioceRos, Joël Pobeda moved to Vierzon from Paris to relocate the family business in cosmetics, CODINA. David Balland who moved to Vierzon in 2008 was recruited as an intern at CODINA. The livestream music start-up aimed to function as a jukebox where subscribers pay only for what they listen to. David Balland heard about Bitcoin and decided to use the protocol for music livestream payments. In mining Bitcoins and seeing the price rapidly increasing, they decided to change their business model to mine and sell Bitcoins and renamed their start-up Chronocoin. Customers could buy Bitcoins online 
using their credit cards, and receive a USB key via UPS with an activation code. Chronocoin grew rapidly and expanded into the majority of the office spaces of the Sologne Technology Park. In March 2013, Chronocoin was the first tenant of the office space dedicated to innovative companies in the Sologne Technology Park.

The two Schumpeterian entrepreneurs were able to seize a WLO thanks to the emergence of a new technology, namely the blockchain, that was not yet mature and geographically unconstrained (Boschma, 1997). The burgeoning path creation and unrelated diversification were far-removed from the existing local knowledge base as they "were perceived like an UFO for the other companies in the technology park and the Municipality" (personal communication, 28 December 2020). In addition to their personal traits and experience, the two Schumpeterian entrepreneurs also benefited from generic resources such as cheap office spaces and access to broadband in the Sologne technology park but most importantly from the French institutional framework. Indeed, RadioceRos received funding supportaround 60,000 euros-from the regional BPI Centre-Val de Loire to develop proof-ofconcepts, to register patents, and for its development as an innovative start-up. RadioceRos was able to capture public funding quite easily as noted: "in Paris, to receive funding from $\mathrm{BPI}$, you have to compete with hundreds of start-ups. Because we were in Vierzon and doing innovation, we stood out, everything went much faster and we quickly had a direct access to someone at BPl" (personal communication, 15 February 2021). Although it was easier for RadioceRos to attract public funding due to regional public financial support mechanisms in France, access to private venture capital in Vierzon is conversely more difficult as those firms are mostly in Paris. The BPI Centre-Val de Loire provided funding to RadioceRos and they supported the change of business models from livestreaming to cryptocurrencies.

\section{The Creation of Ledger}

In late 2013, three startups-Chronocoin, la Maison du Bitcoin, and BTChip_created Ledger. Eric Larchevêque, the grandson of Marc Larchevêque, founded La Maison du Bitcoin based in Paris as an online and brick-and-mortar store for digital currencies. Nicolas Bacca founded BTChip to secure smartcards for Bitcoin. In a twist of fate, Chronocoin's Joël Pobeda bought the Larchevêque family house in Vierzon and then met Eric Larchevêque, of La Maison du Bitcoin, during a Meetup event organised around cryptocurrencies in Paris. For the two entrepreneurs, "it was more of a coincidence that I lived in Eric Larchevêque's house and were both working on Bitcoin, it was fate, we had to work together (personal communication, 15 February 2021). The three start-ups realised that they had complementary assets and had a similar vision for developing a secure hardware wallet for cryptocurrencies, blockchain-based currencies, and blockchain technologies and thus decided to merge. The management decided to locate management, research and development, and marketing in Paris while keeping production, logistics, and customer service in Vierzon. For the Vierzon's team, "it was self-evident that we had to stay in Vierzon and not relocate to Paris" (personal communication, 15 February 2021). The locations in Paris and Vierzon allowed Ledger to adopt compensation and exploitation strategies to reap the benefits of being both in the core and in the periphery simultaneously. Ledger also opened an office in San Francisco to establish a base closer to potential venture capital companies.

\section{The Development of Ledger}

The emblematic Ledger product, the 'Ledger Nano', a hardware wallet for cryptocurrencies launched in December 2014. The Ledger Nano S followed in 2017 and the Ledger Nano X in 2019. In 2017, the Ledger Vault was introduced for institutional clients. Hardware wallets allow users to store cryptocurrencies on a certified smart chip, which can host cryptographic data 
such as private keys. Ledger wallets have their own custom Operating System (BOLOS) to increase security. The purchase of hardware wallets is highly correlated to the price of cryptocurrencies and Bitcoins, which are highly volatile (see Figure 1). After a period of slow growth, the start-up began to grow exponentially in 2017 with the rapid increase of the value of Bitcoin and other cryptocurrencies. From 2014 to 2020, Ledger has grown from 15 to around 350 employees, mostly located in Paris and with around 80 employees in Vierzon (Pétreau, 2021). As of 2021, Ledger has sold more than 3 million hardware wallets and has more than 1.5 million monthly users on Ledger Live.

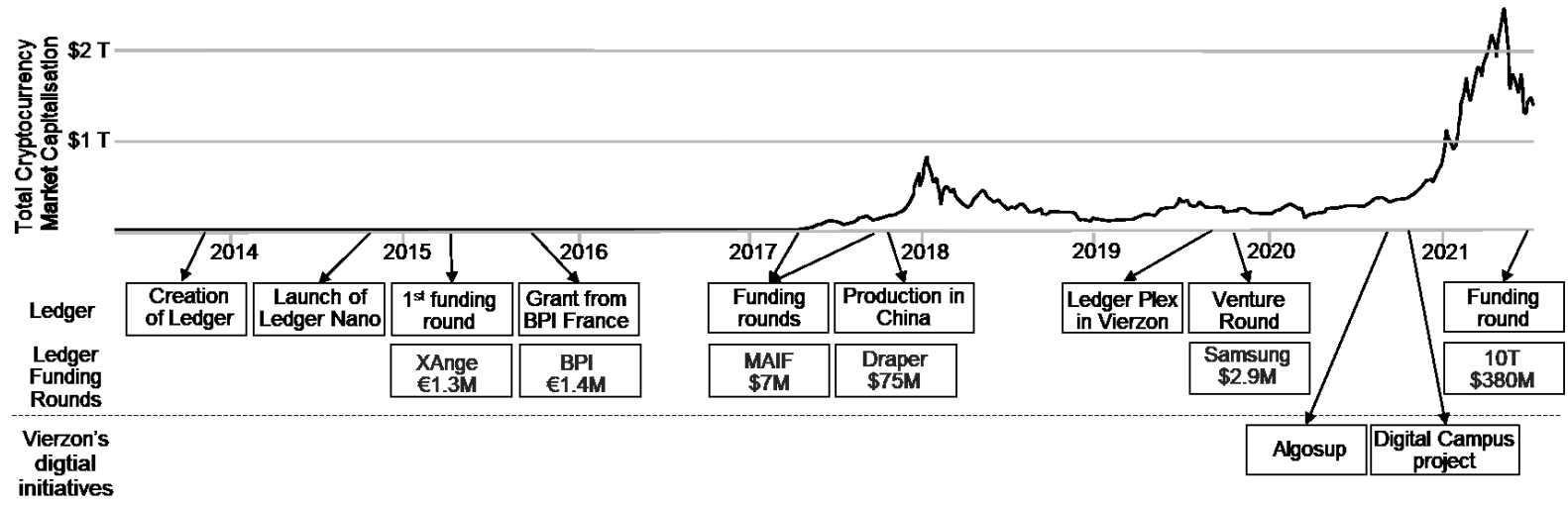

Figure 1. Total cryptocurrency market capitalisation (in USD trillions) with key events for Ledger and Vierzon. Source: own design.

Ledger was able to accelerate its development through eight funding rounds led by XAnge, MAIF Avenir, Draper Esprit, Samsung Ventures, and 10T Holdings making it one of the French unicorn start-ups with an implied valuation of more than $€ 1$ billion (see Figure 1). The consecutive funding rounds were concurrent with a rapid increase of the production of hardware wallets and the need to expand production. In Vierzon, Ledger's growth was also made possible thanks to all the real-estate investments we had just made in creating the Sologne Technology Park. In a sense, it was the right timing" (personal communication, 11 March 2021). In 2017, although Ledger was occupying all the office spaces at the Sologne Technology Park, production could not keep pace with demand, and production had to be temporarily partially outsourced in China.

\section{Ledger in Vierzon-from a WLO to path creation}

Five main factors motivated the decision to remain and repatriate the production in Vierzon and to not outsource it permanently (see table 3 ). The first and the most crucial factor was cost. Although production in China or Poland would have been cheaper, "there are many hidden costs, like traveling there that are difficult to forecast" (personal communication, 11 February 2021). In a pure accounting sense, the costs/benefits analysis of production in Vierzon are known due to the management team's accumulated experience since 2012. Second, Ledger's products are quite specific, which makes logistics easier. Customers often value privacy and security and buy directly from Ledger's website to make sure that they receive non-hacked products. Moreover, there are geopolitical uncertainties related to bitcoins and cryptocurrencies and to the imports and exports of smart cards that are highly regulated. Third, the management team feels that they can count on institutional support from the Region, Municipality, the local development office, and the technology parks. Moreover, the Sologne Technology Park offers ample land to build a new facility at a low price. Fourth, the high brand recognition of Ledger and Vierzon and the department's lack of other job opportunities make it easy to recruit new employees, especially in lower-skilled positions. Indeed, Ledger offers a start-up working environment and work culture that is unique in Vierzon and the department. 
Ledger has even attracted employees from other French regions. Fifth, for the management team, there is also an emotional element intertwined with the irony of being based in Vierzon.

\begin{tabular}{|l|l|}
\hline \multicolumn{1}{|c|}{$\begin{array}{c}\text { Enabling factors } \\
\text { for path creation }\end{array}$} & \multicolumn{1}{|c|}{ Se lected quotes from interviews } \\
Cost & $\begin{array}{l}\text { "In } 2016 \text { and 2017, there were discussions with our board and } \\
\text { investors to have our production outsourced in China or Poland, } \\
\text { we had to convince themthat it made sense financially to produce } \\
\text { in Vierzon." } \\
\text { "We had to conduct a study by independent consultants to prove } \\
\text { to the board that costs were low." }\end{array}$ \\
\hline $\begin{array}{l}\text { Product } \\
\text { specificities }\end{array}$ & $\begin{array}{l}\text { "There are a lot of geopolitical uncertainties around } \\
\text { cryptocurrencies and smart cards." } \\
\text { "We found out that our customers wanted to have their Ledger } \\
\text { directly from the factory to be sure that the product was not } \\
\text { hacked." }\end{array}$ \\
\hline Institutional \\
supports
\end{tabular}

Table 3. Main reasons and selected quotes from Ledger founding team for keeping production in Vierzon. Source: own design

On 26 September 2019, Ledger Plex was inaugurated in Vierzon. It is a 3,700 meter-square facility located in the Sologne Technology Park on a 70,000 meter-square plot. The Ledger Plex, designed by the architectural firm aotu architecture, is composed of office spaces with support functions and software developers, production, warehouse, and shipping buildings. The Ledger Plex was designed so that additional buildings could be constructed and added to the existing structure to meet the start-up growth, up to a total of 15,000 square meters. The construction cost was $€ 8$ million, which was partly covered by Ledger and BPI. In addition, the Intercommunality supported 10 percent of the cost through local public subsidies for real estate projects. BPI, the owner of the building, rents the Ledger Plex to Ledger for 12 years which can be then bought by Ledger for a symbolic euro. The employees of the Ledger Plex assemble hardware wallets. Companies in the Cher department-such as Standard Gum in Bourges until 2019 and Injection Zamak Traitement in Saint-Amand-Montrond-produce the parts. The most essential element, the smart cards, are produced by the French-Italian semiconductor company ST Microelectronics. 
"The Ledger Plex emerges as the necessity to bring back the team together as in our peak of production in 2017, we were in separate buildings and communication was greatly reduced" (personal communication, 15 February 2021).

"In 2019, in France, there were few factories opening. This was especially true for Vierzon that did not have any new factory openings since the closure of Case in 1995" (personal communication, 11 February 2021).

\section{The emergence of institutional entrepreneurship and place-based leadership}

The Intercommunality, which works as the local development office and manages the Sologne Technology Park, supported RadioceRos and Chronocoin in its early-stage development by providing office spaces and other institutional supports. When Ledger raised $€ 1.3$ million in 2015, the start-up presented in national newspapers as a success story from Vierzon (see Chocron, 2019) began to have closer contacts with the Intercommunality and the Municipality and its Mayor, Nicolas Sansu. This special relationship continued with the former CEO of Ledger (2014-2019), Eric Larchevêque becoming the poster child of "Vierzon's economic transformation" (Chocron, 2019). Those frequent interactions led to the emergence of institutional entrepreneurship and place-based leadership made possible thanks to the motivation of Ledger's team to have an impact on Vierzon aligned with the regional and local public actors' desire to feature a local success story. Ledger's management team from Vierzon and Eric Larchevêque actively participate in the design of local initiatives and local development strategies such as Vierzon 2030 and consult at the regional level for the design of digital strategies.

"The Municipality and the Intercommunality were helping us in a very pragmatic way. When we needed spaces in 2017 , they moved the other companies of the technology parks" (personal communication, 11 February 2021).

"We had to convince the companies to move to leave some space for Ledger telling them that Ledger was a real opportunity for Vierzon" (personal communication, 11 March 2021).

"At first, the Municipality did not really believe in what we were doing. They thought that Bitcoin was a fake currency only used in the dark web but when we managed to raise $€ 1.3$ million in 2015 , they started to take us seriously and were in our offices the next day" (personal communication, 15 February 2021).

Ledger acted as an institutional entrepreneur on the local actors thanks to its frequent interactions with the Municipality and Intercommunality. Informal institutions, a source of local pride, use Ledger opportunistically to communicate to the inhabitants and to external stakeholders on Vierzon's economic transformation (see Table 4). Ledger affords legitimacy to formal institutions, such as municipal and Intercommunal teams by enabling economic development projects and the capture of national and regional funding opportunities related to digital projects. For example, Vierzon was among the towns that won the Campus Connecté, a competitive call for projects launched by the national government, in 2020.

Place-based leadership is embodied in the digital campus project that aims to secure path creation in the digital sector. Ledger has boosted the confidence of the local development office to pursue innovative and risky projects. Indeed, the software engineer school Algosup opened in Vierzon in 2020 with heavy support from the Municipality, Intercommunality, and Ledger. Algosup is central to the $€ 3.7$ million rehabilitation project of the Société Française de Vierzon, publicly funded, mostly through regional and local funds, with the intent to create a 
digital campus in 2023 (Pétreau, 2021). The Société Française de Vierzon is a flagship project that would host the CNAM, the Campus Connecté, a start-up incubator in collaboration with Eric Larchevêque, and Algosup that aims to have 300 students in 2030.

\begin{tabular}{|l|l|}
\hline Agency concepts & Selected quotes from interviews \\
\hline Institutional \\
entrepreneurship \\
are always keen to offer visits of the Ledger Plex." \\
"Ledger shows people that something is happening in Vierzon \\
and that medium-sized towns have the capacity to create digital \\
ecosystems." \\
"Ledger gives legitimacy when we speak with the State, Direccte, \\
and the region to pursue our projects." \\
"Ledger spearheaded by Eric Larchevêque and David Balland \\
supported us as a guarantee to show to the region that we are \\
legitimate and serious."
\end{tabular}

Table 4. Selected quotes from Vierzon's Municipality and Intercommunality highlighting the emergence of institutional entrepreneurship and place-based leadership. Source: own design

\section{Conclusions}

The agency perspective explain s the outlier case of Ledger in an unlikely place. Vierzon is a medium-sized old industrial town that is in a structural crisis caused by deindustrialisation starting in the 1970s and accelerating since the closure of the Case factory in 1995. From an EEG perspective, the case of Ledger in Vierzon is a strong outlier as there was neither economic relatedness to the town economic and industrial fabric nor any innovative start-up in novel or frontier technologies. From a RIS perspective, the case of Ledger in Vierzon is also an outlier as the context of an old industrial town in a peripheral area is not conducive to the innovation process. Since the 1990s, local economic development policies were mainly focused on attracting logistics companies and creating a dry port due to the town's transportation hub and strategic location in the middle of France.

Ledger was able to seize a WLO and foster path creation and unrelated diversification in Vierzon for three reasons. First, the emergence of an innovative technology-in the case of Ledger, blockchain and cryptocurrencies-briefly opened a WLO that the Schumpeterian innovative entrepreneurs successfully seized. Second, in addition to their personal traits and experience, the two Schumpeterian entrepreneurs also benefited from generic resources such 
as cheap office spaces and access to broadband in the Sologne technology park but most importantly from the supportive French institutional framework. Indeed, the role of the regional $\mathrm{BPI}$ Centre-Val de Loire, which is a national programme to support and fund innovative startups and companies, the local economic development office, and the regional development agency, Dev' Up, were also key features in the development of Ledger in Vierzon. The case of Ledger shows the importance of national innovation policies from a State-influence market economy on the local context through public funding schemes and local public supports and subsidies. Third, agency and structure mediated chance and serendipity. Ledger is the outcome of a chance encounter between Schumpeterian innovative entrepreneurs, Chronocoin's team, and Eric Larchevêque, the grandson of a famous Vierzon's industrialist. In the SMSTs context, however, Schumpeterian innovative entrepreneurs have a higher chance to meet and interact thanks to the small-scale social network and homophily (see also Roundy, 2017).

Place-based leadership emerged in Vierzon for three main reasons. First, the frequent and privileged interactions between Ledger's founding team and local public actors cemented mutual trust and understanding. These were based on responsive public support which was heightened by Vierzon's absence of alternative in novative entrepreneurial activities. Second, the close collaboration between Ledger's founding team who played the role of institutional entrepreneurs boosted the confidence of the Municipality and Intercommunality to rally local stakeholders to pursue ambitious digital projects, namely the Digital Campus. Third, placebased leadership also opportunistically emerged to leverage the unforeseen development of Ledger in Vierzon to promote vital path creation and unrelated diversification while capturing national and regional funding and media coverage.

The case of Ledger illustrates the role of a WLO and Schumpeterian innovative entrepreneurs to construct the opportunity space. Ledger's founding team managed to seize a WLO thus constructing the opportunity space for Vierzon, to promote blockchain technologies and cryptocurrencies. The local policymakers, however, were not proactive enough to further expand the opportunity space. Until 2016, blockchain technologies and cryptocurrencies were novel frontier technologies with regulatory barriers and uncertainties pushing French entrepreneurs to locate to other countries. In 2014, Ledger played the role of an institutional entrepreneur and promoted multiple initiatives to the Municipality and Intercommunality such as a blockchain school or a free zone to attract blockchain companies to Vierzon offering more certainty in the regulatory framework. The Municipality and Intercommunality, however, did not pursue such initiatives, seeing them as too risky, ambitious, and complex as they would have required the support from the national government. The brief WLO was also missed due to the founding team from Vierzon-namely Eric Larchevêque, Joël Pobeda, and David Ballandwho are keen to have an impact in Vierzon, having less influence on Ledger's strategic decisions than before due to the increased participation of external investors and thus hinders Ledger's future potential place-based leadership.

The case of Ledger in Vierzon offers two main policy recommendations for SMSTs located in peripheral regions in State-influence market economies like France. The first one is for policymakers in SMSTs to take advantage of the national institutional context and public policies to capture funding from schemes for frontier and innovative start-ups. Indeed, the case of Vierzon highlights the relative ease for Ledger to capture public funding with BPI France and to receive enhanced public support thanks to the French institutional framework. Policymakers in SMSTs could take advantage of the national opportunity space to attract risky early-stage start-ups in frontier technologies by communicating the relative ease of capturing public funding and receiving enhanced institutional support from the local and regional economic development offices compared in metropolitan regions. The second one is for local policymakers in SMSTs to take the initiative in identifying agents of change from the local highgrowth and innovative outlier start-ups to initiate risky economic development projects with the objective of seizing brief windows of opportunity and breaking out of existing paths. Although 
related diversification must be the guiding principle for new industrial path development, unrelated diversification can also be pursued as strategic bets when the national institutional context allows SMSTs to capture national public funding opportunities and policies.

There are two avenues for future research that could be pursued following this case-study of Ledger in Vierzon. First, researchers could investigate such outlier cases in different national institutional frameworks to identify if such outlier cases can emerge outside State-influence market economies. Second, researchers could empirically investigate whether unrelated diversification and path creation are more likely in a local context with low economic relatedness during the emergence of a new technology, such as blockchain.. Such an empirical study could validate the WLO-concept and corroborate the policy recommendations for path creation and unrelated diversification. This proposed future research would also respond to the limitations of such an outlier case and generalise its findings.

\section{Acknowledgements}

The authors thank Markus Grillitsch, Aixa Aleman-Diaz, two anonymous referees and the journal editor, as well as participants of the ERSA Conference 2021 and the Eu-SPRI Early Career Researcher (ECR) Webinar Series for their helpful comments on earlier versions of this paper.

\section{References}

Adler, P., Florida, R., King, K., \& Mellander, C. (2019). The city and high-tech startups: The spatial organization of Schumpeterian entrepreneurship. Cities, 87, 121-130. https://doi.org/10.1016/j.cities.2018.12.013

Asheim, B. T., Boschma, R., \& Cooke, P. (2011). Constructing Regional Advantage: Platform Policies Based on Related Variety and Differentiated Knowledge Bases. Regional Studies, 45(7), 893904. https://doi.org/10.1080/00343404.2010.543126

Barca, F., Mccann, P. , \& Rodríguez-Pose, A. (2012). The case for regional development intervention: Place-based versus place-neutral approaches. Journal of Regional Science, 52(1), 134-152. https://doi.org/10.1111/j.1467-9787.2011.00756.x

Battilana, J., Leca, B., \& Boxenbaum, E. (2009). How Actors Change Institutions: Towards a Theory of Institutional Entrepreneurship. The Academy of Management Annals, 3(1), 65-107. https://doi.org/10.1080/19416520903053598

Beer, A. (2014). Leadership and the governance of rural communities. Journal of Rural Studies, 34, 254-262. https://doi.org/10.1016/j.jrurstud.2014.01.007

Beer, A., \& Clower, T. (2014). Mobilizing leadership in cities and regions. Regional Studies, Regional Science, 1(1), 5-20. https://doi.org/10.1080/21681376.2013.869428

Béhar, D. (2019). From equality to territorial cohesion. Géographie, économie, société, 21(3), 251-267.

Bole, D., Kozina, J., \& Tiran, J. (2020). The socioeconomic performance of small and medium sized industrial towns: Slovenian perspectives. Moravian Geographical Reports, 28(1), 16-28. https://doi.org/10.2478/mgr-2020-0002

Boschma, R.A. (1997). New industries and windows of locational opportunity. A long-term analysis of Belgium. Erdkunde, 51, 12-22.

Boschma, R.A. (2017). Relatedness as driver of regional diversification: A research agenda. Regional Studies, 51(3), 351-364.

Boschma, R.A. \& van der Knaap, B. (1997). New technology and windows of locational opportunity. In Reijnders, J. (ed.). Economics and Evolution (pp 171-202). Cheltenham: Edward Elgar.

Boschma, R.A. (2007). Path creation, path dependence and regional development. In Simmie, J.and Carpenter, J. (Eds.). Path Dependence and the Evolution of City Regional Economies, Working paper Series, No. 197, (40-55). Oxford: Oxford Brookes University.

CDC INFOS. (2021). Communauté de Communes. JOURNAL D'INFORMATION CDC, February 2021, 32. Retrieved fromhttps://www.cc-vierzon.fr/wp-content/uploads/2021/02/CDCINFOS32_Fevier2021_BD.pdf 
Chocron, V. (2019). Vierzon place tous ses espoirs dans le bitcoin. Le Monde. Retrieved from https://www.lemonde.fr/economie/article/2019/04/23/vierzon-place-tous-ses-espoirs-dans-lebitcoin 5453639 3234.html

Crespo, J. (2021). Agencies, scales and times of path creation: the case of loT in Toulouse. Regional Science Policy \& Practice, rsp3.12390. https://doi.org/10.1111/rsp3.12390

Creswell, J. W. (2013). Qualitative Inquiry and Research Design: Choosing Among Five Approaches. Thousand Oaks: Sage Publications

DDT. (2020). Portraits du Cher. Bourges: DDT du Cher - Service connaissance, aménagement et planification - Bureau des avis et expertises territoriales.

Dijkstra, L., Garcilazo, E., \& McCann, P. (2013). The economic performance of European cities and city regions: Myths and realities. European Planning Studies, 21(3), 334-354.

Döringer, S. (2020). Individual agency and socio-spatial change in regional development: Conceptualizing governance entrepreneurship. Geography Compass, 14(5), 1-17. https://doi.org/10.1111/gec3.12486

Eder, J. (2019). Innovation in the Periphery: A Critical Survey and Research Agenda. International Regional Science Review, 42(2), 119-146. https://doi.org/10.1177/0160017618764279

Eder, J., \& Trippl, M. (2019). Innovation in the periphery: Compensation and exploitation strategies. Growth and Change, 50(4), 1511-1531.

Feldman, M. P., Francis, J., \& Bercovitz, J. (2005). Creating a cluster while building a firm: Entrepreneurs and the formation of industrial clusters. Regional Studies, 39(1), 129-141. https://doi.org/10.1080/0034340052000320888

Gosens, J., Gilmanova, A., \& Lilliestam, J. (2021). Windows of opportunity for catching up in formative clean-tech sectors and the rise of China in concentrated solar power. Environmental innovation and societal transitions, 39, 86-106.

Grabher, G. (2018). Marginality as strategy: Leveraging peripherality for creativity. Environment and Planning A, 50(8), 1785-1794. https://doi.org/10.1177/0308518X18784021

Gregory, D., Johnston, R., Pratt, G., Watts, M., Wathmore, S. (2009). The Dictionary of Human Geography. Oxford: Wiley-Blackwell.

Grillitsch, M., \& Asheim, B. (2018). Place-based innovation policy for industrial diversification in regions. European Planning Studies, 26(8), 1638-1662.

Grillitsch, M., \& Sotarauta, M. (2020). Trinity of change agency, regional development paths and opportunity spaces. Progress in human geography, 44(4), 704-723. https://doi.org/10.1177/0309132519853870

Grillitsch, M., Rekers, J. V., \& Sotarauta, M. (2021). Investigating agency: methodological and empirical challenges. In Handbook on city and regional leadership. Cheltenham, UK: Edward Elgar Publishing

Hamdouch, A., Demaziere, C., \& Banovac, K. (2017). The Socio-Economic Profiles of Small and Medium-Sized Towns: Insights from European Case Studies. Tijdschrift Voor Economische En Sociale Geografie, 108(4), 456-471. https://doi.org/10.1111/tesg. 12254

Hassink, R., Isaksen, A., \& Trippl, M. (2019). Towards a comprehensive understanding of new regional industrial path development. Regional Studies, 53(11), 1636-1645. https://doi.org/10.1080/00343404.2019.1566704

INSEE. (2021). Comparateur de territoire. Retrieved from https://www.insee.fr/fr/statistiques/1405599?geo=COM-18279

Isaksen, A., Jakobsen, S. E., Njøs, R., \& Normann, R. (2019). Regional industrial restructuring resulting from individual and system agency. Innovation: The European Journal of Social Science Research, 32(1), 48-65.

Jacobs, J. (1969). The Economy of Cities. New York: Vintage Publishing.

Le Berry. (2018). Larchevêque a repris l'usine déliquescente de son père pour bâtir son empire. Le Berry Républicain. Retrieved from https://www.leberry.fr/vierzon-18100/actualites/a-20-ans-levierzonnais-marc-larcheveque-a-repris-lusine-deliquescente-de-son-pere-pour-batir-sonempire 12919441/

Lee, K., Lim, C., \& Song, W. (2005). Emerging digital technology as a window of opportunity and technological leapfrogging: catch-up in digital TV by the Korean firms. International Journal of Technology Management, 29(1-2), 40-63.

Low, S. A., \& Isserman, A. M. (2015). Where Are the Innovative Entrepreneurs? Identifying Innovative Industries and Measuring Innovative Entrepreneurship. International Regional Science Review, 38(2), 171-201. https://doi.org/10.1177/0160017613484926

Mack, E., \& Mayer, H. (2015). The evolutionary dynamics of entrepreneurial ecosystems. Urban Studies, 53(10), 2118-2133. https://doi.org/10.1177/0042098015586547 
Mayer, H. (2011). Entrepreneurship and innovation in second tier regions. Cheltenham, UK: Edward Elgar.

Miörner, J. (2020). Contextualizing agency in new path development: how system selectivity shapes regional reconfiguration capacity. Regional Studies, 0(0), 1-13. https://doi.org/10.1080/00343404.2020.1854713

Morisson, A., \& Panetti, E. (2020). Institutional entrepreneurs and socio-institutional changes in Medellín, Colombia. Regional Studies, Regional Science, 7(1), 35-51. https://doi.org/10.1080/21681376.2019.1703796

Moulaert, F., Jessop, B., \& Mehmood, A. (2016). Agency, structure, institutions, discourse (ASID) in urban and regional development. International Journal of Urban Sciences, 20(2), 167-187. https://doi.org/10.1080/12265934.2016.1182054

Neffke, F., Henning, M., \& Boschma, R. (2011). How Do Regions Diversify over Time? Industry Relatedness and the Development of New Growth Paths in Regions. Economic Geography, 87(3), 237-265. https://doi.org/10.1111/j.1944-8287.2011.01121.x

North, D. C. (1990). Institutions, Institutional Change and Economic Performance. Cambridge: Cambridge University Press. https://doi.org/10.1017/cbo9780511808678

Patton, M. Q. (2015). Qualitative Evaluation and Research Methods. Thousand Oaks: SAGE Publications.

Perez, C. \& Soete, L. (1988). Catching up in technology: entry barriers and windows of opportunity. In Dosi, G., Freeman, C., Nelson, R., Silverberg, G., \& Soete, L. (eds.). Technical Change and Economic Theory (pp. 458-79). London: Pinter Publishers.

Pétreau, V. (2021). Un incubateur de startups créé par Éric Lachevêque dans le Campus numérique. Le Berry Républicain. Retrieved from https://www.leberry.fr/vierzon-18100/actualites/unincubateur-de-startups-cree-par-eric-lacheveque-dans-le-campus-numerique_13958346/

Pinheiro, F. L., Alshamsi, A., Hartmann, D., Boschma, R., \& Hidalgo, C. (2018). Shōoting low or high: Do countries benefit from entering unrelated activities?. Papers in Evolutionary Economic Geography, 18(07). Utrecht: Utrecht University.

Pylak, K., \& Kogler, D. F. (2021). Successful economic diversification in less developed regions: longterm trends in turbulent times. Regional Studies, 1-14. https://doi.org/10.1080/00343404.2020.1862782

Rodríguez-Pose, A., \& Griffiths, J. (2021). Developing intermediate cities. Regional Science Policy \& Practice, 13(3), 441-456.

Roundy, P. T. (2017). "Small town" entrepreneurial ecosystems: Implications for developed and emerging economies. Journal of Entrepreneurship in Emerging Economies, 9(3),238-262.

Schmidt, V. A. (2009). Putting the Political Back into Political Economy by Bringing the State Back in Yet Again. World Politics, 61.

Schumpeter, J. A. (1942). Socialism, Capitalism and Democracy. New York: Harper and Brothers.

Scott, A.J. \& Storper, M. (1987). High technology industry and regional development. A theoretical critique and reconstruction. International Social Science Journal, 112, 215-232.

Servillo, L., Atkinson, R., \& Hamdouch, A. (2017). Small and Medium-Sized Towns in Europe: Conceptual, Methodological and Policy Issues. Tijdschrift Voor Economische En Sociale Geografie, 108(4), 365-379. https://doi.org/10.1111/tesg.12252

Simmie, J. (2020). Agency, new technological path creation and long waves of local economic growth in Oxfordshire. Local Economy, 35(8), 723-746.

Sotarauta, M. (2016). Place leadership, governance and power. Administration, 64(3-4), 45-58. https://doi.org/10.1515/admin-2016-0024

Sotarauta, M. (2020). Place-based Policy, Place Sensitivity and Place Leadership. Sente Working Papers 46/2020. Tampere: Tampere University.

Sotarauta, M., \& Beer, A. (2017). Governance, agency and place leadership: lessons from a crossnational analysis. Regional Studies, 51(2), 210-223. https://doi.org/10.1080/00343404.2015.1119265

Sotarauta, M., \& Mustikkamäki, N. (2015). Institutional Entrepreneurship, Power, and Knowledge in Innovation Systems: Institutionalization of Regenerative Medicine in Tampere, Finland. Environment and Planning C: Government and Policy, 33(2), 342-357. https://doi.org/10.1068/c12297r

Sotarauta, M., \& Pulkkinen, R. (2011). Institutional Entrepreneurship for Knowledge Regions: In Search of a Fresh Set of Questions for Regional Innovation Studies. Environment and Planning C: Government and Policy, 29(1), 96-112. https://doi.org/10.1068/c1066r 
Sotarauta, M., Beer, A., \& Gibney, J. (2017). Making sense of leadership in urban and regional development. Regional Studies, 51(2), 187-193. https://doi.org/10.1080/00343404.2016.1267340

Sotarauta, M., Kurikka, H., \& Kolehmainen, J. (2021). Patterns of place leadership: institutional change and path development in peripheral regions. In Sotarauta, M. \& Beer, A. (Eds.), Handbook on City and Regional Leadership. Cheltenham: Edward Elgar Publishing

Stake, R. E. (2013). Multiple Case Study Analysis. New York: Guilford Press.

Storper, M. \& Walker, R. (1989). The capitalist imperative; territory, technology and industrial growth. New York: Basil Blackwell.

Strambach, S., \& Klement, B. (2012). Cumulative and Combinatorial Micro-dynamics of Knowledge: The Role of Space and Place in Knowledge Integration. European Planning Studies, 20(11), 1843-1866. https://doi.org/10.1080/09654313.2012.723424

Tödtling, F., \& Trippl, M. (2005). One size fits all?: Towards a differentiated regional innovation policy approach. Research policy, 34(8), 1203-1219.

Trippl, M., Baumgartinger-Seiringer, S., Frangenheim, A., Isaksen, A., \& Rypestøl, J. O. (2020). Unravelling green regional industrial path development: Regional preconditions, asset modification and agency. Geoforum, 111, 189-197. https://doi.org/10.1016/j.geoforum.2020.02.016

Weik, E. (2011). Institutional entrepreneurship and agency. Journal for the Theory of Social Behaviour, 41(4), 466-481. https://doi.org/10.1111/j.1468-5914.2011.00467.x

Yin, R. K. (2013). Case study research: Design and methods. Thousand Oaks: SAGE Publications.

Zheng, Z., Xie, S., Dai, H. N., Chen, X, \& Wang, H. (2018). Blockchain challenges and opportunities: A survey. International Journal of Web and Grid Services, 14(4), 352-375. 